\title{
Identifikasi Model dari Pesawat Udara Tanpa Awak Sayap Tetap Jenis Bixler
}

\author{
Abdul Majid ${ }^{* 1}$, Raden Sumiharto ${ }^{2}$, Setyawan Bekti Wibisono ${ }^{3}$ \\ ${ }^{1}$ Prodi Elektronika dan Instrumentasi Jurusan Ilmu Komputer dan Elektronika, FMIPA UGM \\ ${ }^{2}$ Jurusan Ilmu Komputer dan Elektronika, FMIPA UGM \\ ${ }^{3}$ Diploma III Teknik Mesin, Sekolah Vokasi UGM \\ e-mail: *1 dok_majid@yahoo.co.id, ${ }^{2}$ mmx_77@yahoo.com, ${ }^{3}$ setyawanbw@gmail.com
}

\begin{abstract}
Abstrak
Model terbang merupakan bagian penting dalam pembangunan sistem kontrol suatu pesawat udara tanpa awak sayap tetap, terutama dalam pembangunan sistem kendali mandiri atau autopilot pesawat. Dengan model terbang, gerak terbang pesawat dapat direpresentasikan dan disimulasikan.

Pada penelitian ini, model terbang dihasilkan melalui identifikasi sistem atau pemodelan pesawat udara tanpa awak sayap tetap jenis Bixler. Identifikasi sistem dilakukan berdasarkan eksperimen (pengambilan data terbang) dan digunakan struktur model statespace. Terdapat tiga tahapan dalam penelitian ini, pemodelan gerak terbang pesawat, pengambilan data terbang, dan identifikasi model terbang. Melalui tiga tahapan tersebut, diperoleh model terbang pesawat sayap tetap jenis Bixler yang dapat merepresentasikan gerak terbang pesawat yang terbagi dalam 2 mode, mode longitudinal dan mode lateral.

Diperoleh model terbang mode longitudinal pesawat udara tanpa awak sayap tetap jenis Bixler menggunakan 13 parameter menggunakan struktur model state-space orde 4. Model terbang mode lateral pesawat udara tanpa awak sayap tetap jenis Bixler menggunakan 11 parameter menggunakan struktur model state-space orde 4.
\end{abstract}

Kata kunci-UAV, Identifikasi Sistem, Pemodelan

\begin{abstract}
Flight model is one of importing thing in fixed-wing unmanned aerial vehicle (UAV) control system development, mainly in the aircraft autopilot. Through this flight model, the aircraft motion can be represented and simulated.

In this research, the flight model is obtained through system identification and system modelling of Bixler fixed-wing unmanned aerial vehicle. System identification is based on experiment data and use state-space model structure. There are three stages in this research, aircraft motion system modelling, flight data collecting, and flight model identification. Through those three stages, Bixler fixed-wing unmanned aerial vehicle flight model is obtained as represented in two modes, longitudinal mode and lateral mode

The Bixler fixed-wing unmanned aerial vehicle longitudinal mode flight model is obtained using 13 parameters. The lateral mode is obtained using 11 parameters. All modes are in $4^{\text {th }}$ order state space model structure.
\end{abstract}

Keywords - UAV, System Identification, Modelling

Received January 20 ${ }^{\text {th } 2014 ; \text { Revised August 21 }}$, 2014; Accepted April 15 ${ }^{\text {th }}, 2015$ 


\section{PENDAHULUAN}

Derkembangan teknologi UAV (unmanned aerial vehicle) atau pesawat tanpa awak semakin berkembang luas dengan semakin banyaknya penggunaan UAV di dunia. Teknologi UAV sendiri pada dasarnya sama dengan pesawat berawak. Pada UAV terdapat sistem aerodinamika, kontrol atau kendali, propulsi, komunikasi, dan lain-lain. Namun yang membedakannya dengan pesawat berawak, sistem kontrol dan komunikasi memegang peranan besar dalam operasional sebuah UAV. Hal ini dikarenakan UAV dikendalikan dari jauh jauh, sehingga kendali diberikan melalui komunikasi tanpa kabel (wireless). Karena posisi yang penting tersebut, maka perlunya dilakukan penelitian-penelitian mengenai sistem kontrol dan komunikasi UAV ke depannya.

Sebagai sebuah sistem yang memiliki peran penting dalam sebuah UAV, sistem kontrol dapat dibagi menjadi beberapa bidang, diantaranya sistem kendali mandiri (autopilot), logika terbang, model terbang, logika navigasi, dan lainnya. Model terbang diperlukan agar dalam UAV memiliki kontrol yang presisi, karena model terbang dapat merepresentasikan gerak terbang UAV.

Pada pemodelan gerak terbang UAV, dikenal teknik identifikasi sistem. Identifikasi sistem adalah teknik pemodelan dengan mengembangkan model sistem secara umum atau generik, untuk parameter-parameter model diidentifikasi dari data input dan output sistem, kemudian dengan struktur model tertentu akan menghasilkan model yang akan menjadi representasi dari sebuah sistem. Untuk struktur model yang dipakai pada penelitian ini, digunakan struktur model state-space. Data yang digunakan untuk identifikasi sistem dengan struktur model state-spaceini menggunakan data terbang pesawat udara tanpa awak sayap tetap. Sehingga perlu dilakukan pengambilan data terbang.

\section{METODE PENELITIAN}

\subsection{Identifikasi Sistem}

Identifikasi sistem adalah metedologi untuk membangun model matematika dari suatu sistem dinamis berdasarkan perhitungan dari sinyal input dan output sistem. Secara konsep, identifikasi sistem merupakan pemodelan sistem dinamis dari data yang dihasilkan dalam eksperimen [1]. Identifikasi sistem dapat dijabarkan sesuai Gambar 1.

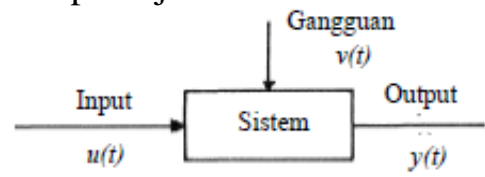

Gambar 1 Sistem dinamis dengan input $u(t)$, output $y(t)$ dan gangguan disturbance $v(t)$, dengan $t$ menunjukkan waktu [2].

Identifikasi sistem melibatkan tiga unsur dasar berikut:

1. Data input dan output.

2. Struktur model.

3. Kriteria untuk memilih model tertentu dalam mengatur data berdasarkan informasi dalam data.

Secara garis besar, langkah-langkah identifikasi sistem dapat dijabarkan sesuai Gambar 2. 


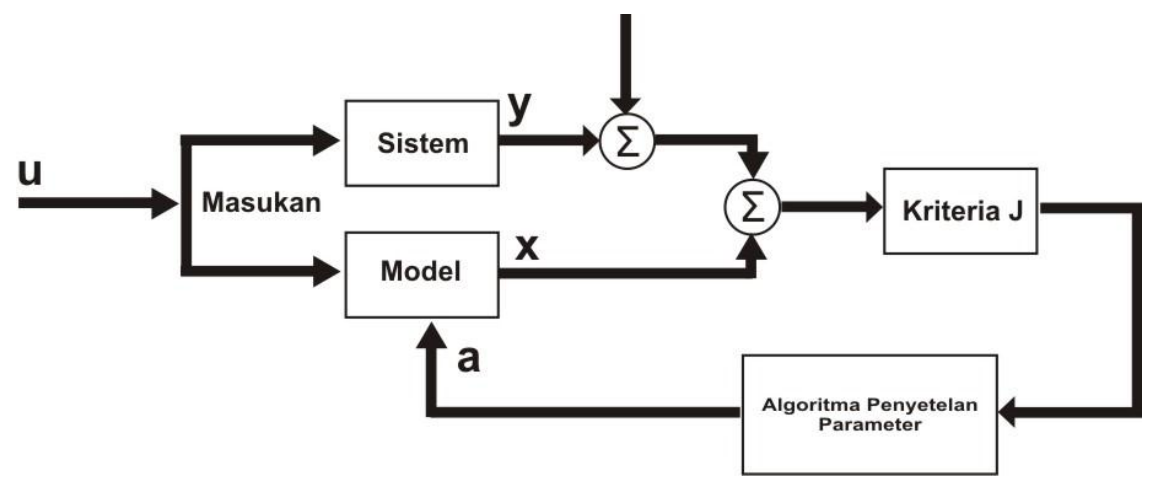

Gambar 2 Langkah-langkah identifikasi sistem [3].

\subsection{Struktur Model State-Space}

State space adalah salah satu bentuk struktur model identifikasi sistem. Model state space dapat digunakan dalam berbagai bentuk input-output, yaitu SISO (single input-single output) dan MIMO (multiple input-multiple output). Bentuk umum model state space adalah sebagaimana persamaan (1) dan (2):

Dengan:

$$
\begin{aligned}
& \dot{x}=A x+B u \\
& y=C x+D u
\end{aligned}
$$

$$
\dot{x}=\frac{d x}{d t}
$$

$$
\begin{array}{ll}
\mathrm{x} & =\text { State vector (vector keadaan) } \\
\mathrm{u} & =\text { Vektor input } \\
\mathrm{y} & =\text { Vektor output } \\
\mathrm{A}, \mathrm{B}, \mathrm{C}, \mathrm{D} & \quad \text { = Matriks state space yang mengekspresikan sistem dinamis }
\end{array}
$$

\subsection{Pesawat Udara Tanpa Awak}

Pada umumnya pesawat udara tanpa awak sama dengan pesawat udara berawak, terdapat beberapa parameter gaya, kecepatan, dan orientasi yang bekerja sesuai dengan yang ditunjukkan Gambar 3 di bawah ini.

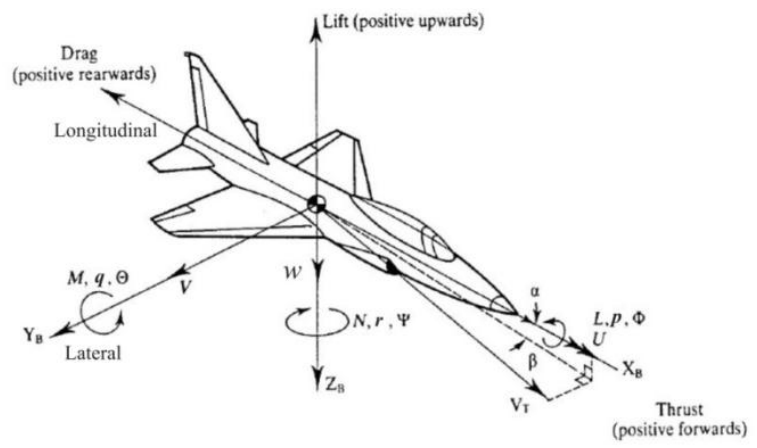

Gambar 3 Definisi gaya, kecepatan, momen, dan orientasi pesawat [4].

Dengan:

$u, v, w \quad$ Kecepatan translasi pada sumbu $\mathrm{x}$, sumbu $\mathrm{y}$, dan sumbu $\mathrm{z}$

$L, M, N \quad$ Momen aerodinamika sumbu $x, y$, dan $z$

$\phi, \theta, \psi \quad$ Sudut roll, pitch, dan yaw

$p, q, r \quad$ Kecepatan sudut roll, pitch, dan yaw

$\alpha \quad$ Sudut serang pesawat/angle-of-attack (AoA) 
$\beta \quad$ Sudut sideslip

$\delta_{e} \quad$ Defleksi elevator

$\delta_{a} \quad$ Defleksi aileron

Gerak terbang pesawat dapat dibagi 2:

- Gerak terbang mode longitudinal, yaitu gerak translasi pesawat pada sumbu $x$ dan $z$, serta gerak rotasi pesawat pada sumbu $y$. Gerak ini dibutuhkan untuk gerak naik-turun pesawat. Untuk kontrol naik-turun pesawat, digunakan elevator pesawat.

- Gerak terbang mode lateral, yaitu gerak translasi pesawat pada sumbu $y$, serta gerak rotasi pesawat pada sumbu $x$ dan $z$. Gerak ini dibutuhkan untuk gerakan membelok pesawat (belok kanan-kiri). Untuk kontrol belok kanan-kiri pesawat, digunakan aileron pesawat.

\subsection{Rancangan Keseluruhan Penelitian}

Secara umum, penelitian ini dapat digambarkan sebagaimana pada Gambar 4 berikut.

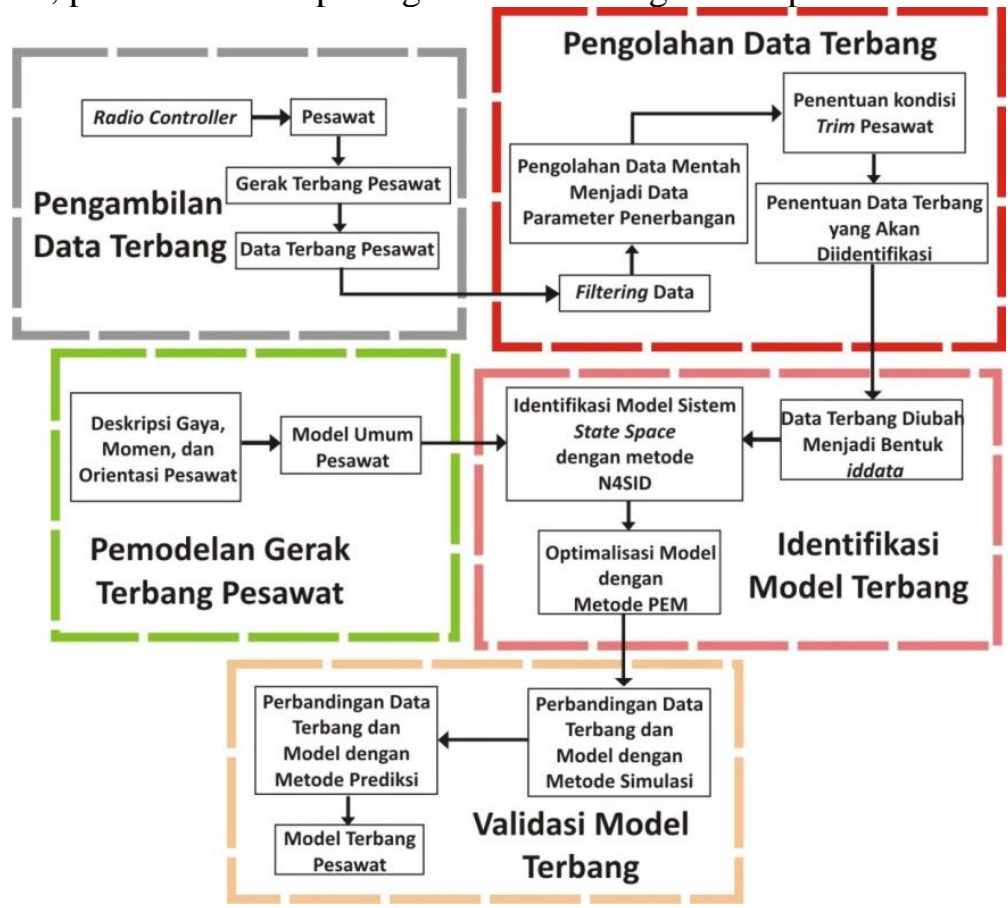

Gambar 4 Rancangan Keseluruhan Penelitian.

\subsection{Implementasi Perangkat Keras}

Rancangan perangkat keras meliputi rancangan pesawat, radio controller (RC), dan muatan (payload) berupa ADAHRS (air data, attitude, and heading reference system) untuk pengambilan data terbang. Gambar 5 dibawaBerikut ini skema perangkat keras yang digunakan dalam penelitian ini.

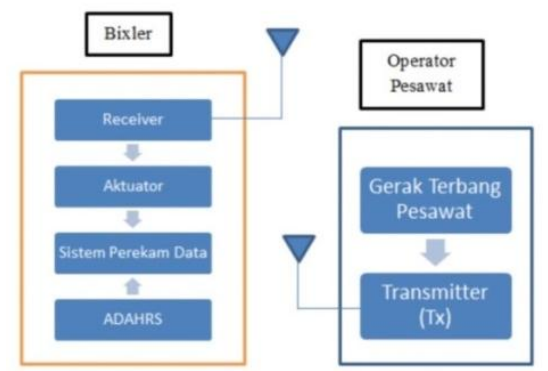

Gambar 5 Implementasi Perangkat keras.

IJEIS Vol. 5, No. 1, April 2015 : 43 - 54 


\subsubsection{Implementasi Pesawat}

Pesawat yang digunakan adalah pesawat Radio Controller (RC) Bixler. Pesawat Bixler sebagaimana ditunjukkan Gambar 6 merupakan pesawat yang banyak dipakai dalam dunia aeromodeling. Pesawat ini dilengkapi 4 sistem kendali (aileron, rudder, elevator, dan throttle). Berikut ini data teknis pesawat bixler [5].

- Material : EPO Foam

- Lebar sayap : $1400 \mathrm{~mm}$

- Panjang : $925 \mathrm{~mm}$

- Luas sayap : $: 26 \mathrm{dm} 2$

- Berat : $650 \mathrm{~g}$

- Motor : 2620-1900kv Brushless Outrunner

- ESC :20A w/BECServo: 4 x 9g

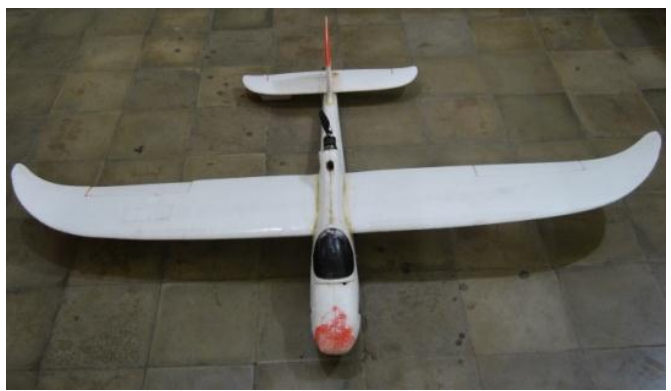

Gambar 6 Pesawat Bixler.

Aktuator yang digunakan adalah mini-servo dan brushless-motor. Semua aktuator dihubungkan dengan $R C$ receiver. Berikut ini pengaturan hubungan $R C$ receiver dengan aktuator:

- Channel 1 dihubungkan dengan 2 mini-servo aileron.

- Channel 2 dihubungkan dengan mini-servo elevator.

- Channel 3 dihubungkan dengan ESC (electronic speed controller).

- Channel 4 dihubungkan dengan mini-servo rudder.

Selain dihubungkan dengan aktuator, port channel 1-4 receiver dihubungkan pula dengan Arduino Due melalui modul aktuator. Fungsinya yaitu sebagai parallel dari RC receiver agar input yang dikirimkan oleh transmitter dapat dibaca dan kemudian direkam oleh modul perekam data. Gambar 7 berikut ini adalah implementasi dari modul aktuator.

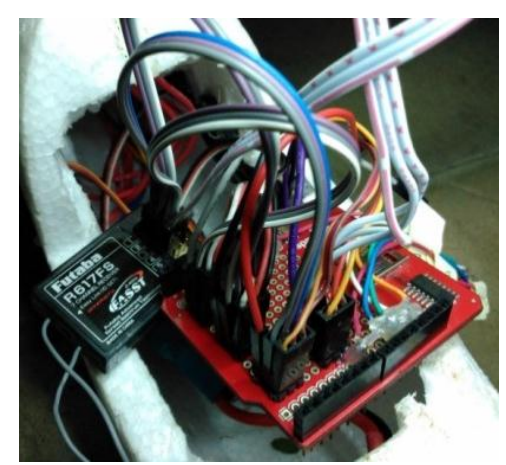

Gambar 7 implementasi modul aktuator dengan Arduino Due.

Pada penelitian ini digunakan payload berupa ADAHRS (air data, attitude, and heading reference system) yang berfungsi untuk memantau sikap pesawat. ADAHRS terdiri dari beberapa sensor seperti IMU (inertial measurement unit) yang terdiri dari accelerometer,

Identifikasi Model dari Pesawat Udara Tanpa Awak Sayap Tetap Jenis Bixler (Abdul Majid) 
gyroscope, dan magnetometer, kemudian barometer, pressure sensor, dan GPS (Global Positioning System) receiver. Accelerometer dan gyroscope berfungsi memantau sikap pesawat (sudut roll, pitch, dan yaw), magnetomer berfungsi memantau arah terbang pesawat, barometer berfungsi untuk memantau ketinggian terbang pesawat terhadap permukaan laut, pressure sensor berfungsi untuk memantau kecepatan pesawat (dengan dihubungkan dengan probe), serta GPS receiver berfungsi untuk memantau posisi pesawat. ADAHRS yang dipakai dalam penelitian ini ditunjukkan pada Gambar 8 dan spesifikasinya ditunjukkan pada Tabel 1 .

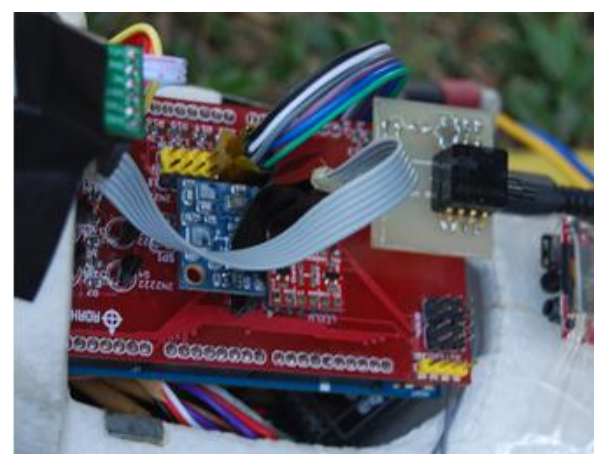

Gambar 8 Implementasi ADAHRS.

Spesifikasi dari ADAHRS yang digunakan[6]:

- Kontroler

: Arduino Due

- Sensor-sensor

- Sensor IMU

: MPU6050 dan HMC5883 S

- Sensor Ketinggian

: MS611

- Sensor Kecepatan Udara

: MPXV5004D

- GPS

: SKM53

Tabel 1 Spesifikasi ADAHRS [6].

\begin{tabular}{|c|l|}
\hline Parameter & \multicolumn{1}{|c|}{ Spesifikasi } \\
\hline Yaw & $\begin{array}{l}\text { - Offset } 0,2^{\circ} \\
\text { - Standar Deviasi Statis } 0,07^{\circ} \\
\text { - Ralat rata-rata } 0,25^{\circ}\end{array}$ \\
\hline Pitch & $\begin{array}{l}\text { - Offset } 0,14^{\circ} \\
\text { - Standar Deviasi Statis } 0,04^{\circ} \\
\text { - Ralat rata-rata } 0,24^{\circ}\end{array}$ \\
\hline \multirow{2}{*}{ Roll } & $\begin{array}{l}\text { - Offset } 0,6^{\circ} \\
\text { - Standar Deviasi Statis } 0.18^{\circ} \\
\text { - Ralat rata-rata } 0,64^{\circ}\end{array}$ \\
\hline Ketinggian barometrik & $\begin{array}{l}\text { - Ralat rata-rata } 0,63 \mathrm{~m} \\
\text { - Standar Deviasi } 0,17 \mathrm{~m}\end{array}$ \\
\hline \multirow{2}{*}{ Kecepatan udara } & $\begin{array}{l}\text { - Ralat rata-rata } 13,85 \mathrm{~km} / \mathrm{jam} \\
\text { - Standar deviasi } 2,31 \mathrm{~km} / \mathrm{jam}\end{array}$ \\
\hline \multirow{2}{*}{ GPS } & $\begin{array}{l}\text { - Ralat rata-rata koordinat } 6,68 \mathrm{~m} \\
\text { - Ralat rata-rata ketinggian } 12,58 \mathrm{~m}\end{array}$ \\
\hline
\end{tabular}

Untuk merekam data yang dibaca oleh ADAHRS dan modul aktuator, diperlukan sebuah sistem perekam data. Media penyimpanan yang digunakan berupa Micro SD. Digunakan modul Micro SD yang diproduksi oleh Sparkfun Electronics sebagaimana Gambar 9 berikut ini.

IJEIS Vol. 5, No. 1, April 2015: 43 - 54 


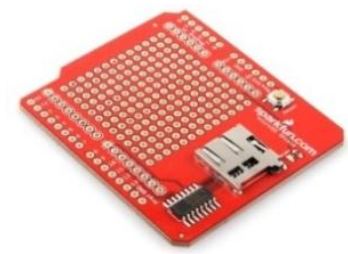

Gambar 9 Modul micro SD [7].

\subsubsection{Implementasi Transmitter dan Receiver}

Transmitter dan receiver yang digunakan adalah jenis Futaba FASST 7C yang memiliki 7 Channel, yang ditunjukkan pada Gambar 10. Transmitter dan receiver ini sudah cukup untuk penelitian ini, sebab pesawat Bixler yang digunakan hanya membutuhkan 4 Channel yaitu Channel 1-4. Futaba FASST 7C memiliki frekuensi $2.4 \mathrm{GHz}$ dan memiliki jarak jangkau sekitar 400-500 meter dengan kualitas sinyal yang dihasilkan salah satu yang terbaik dikelasnya.

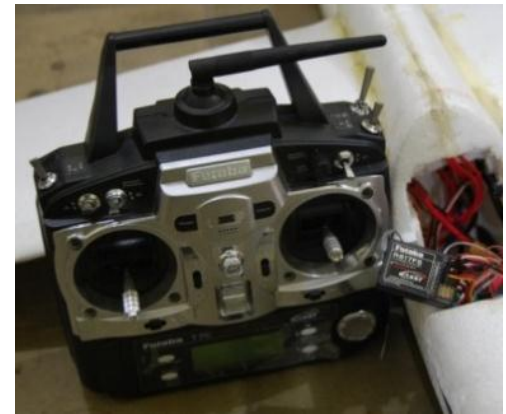

Gambar 10 Implementasi Transmitter dan Receiver

\subsection{Implementasi Pengambilan Data Terbang}

Pengambilan data terbang mencakup 2 hal, data input dan output pesawat. Data input meliputi data input yang diberikan kepada aktuator melalui radio controller, sedangkan data output meliputi data sikap, posisi, dan kecepatan pesawat. Data terbang yang dihasilkan berguna untuk tahap selanjutnya, yaitu identifikasi model terbang pesawat.

Untuk penelitian ini, input pada pesawat berupa doublet input. Doublet input adalah variasi input dengan diberikan sinyal PWM tinggi selama waktu $t$ dan kemudian langsung diberikan sinyal PWM rendah selama waktu $t$ pula. Doublet input banyak digunakan oleh peneliti dalam melakukan pemodelan dan perusahaan Boeing ketika melakukan identifikasi sistem pesawat tempur F-15 Eagle [8].

Pada penelitian ini pemodelan akan dibagi 2, mode longitudinal dan mode lateral. Pada mode longitudinal,variasi doublet input diberikan pada channel 2 atau elevator, kemudian pada mode lateral, variasi doublet input diberikan pada channel 1 yaitu aileron. Sebelum diberikan doublet input, peswat dikondisikan dalam keadaan trim dan level, yaitu pesawat dianggap dalam keadaan terbang lurus dan sayap kanan-kiri pesawat dalam keadaan sama secara horizontal. Diagram prosedur pengambilan data terbang dapat dilihat pada Gambar 11 berikut. 


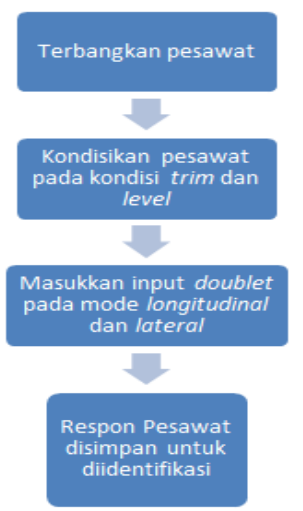

Gambar 11 Diagram prosedur pengambilan data terbang

\subsection{Implementasi Identifikasi Sistem}

Identifikasi model terbang pesawat udara tanpa awak sayap tetap pada penelitian ini menggunakan struktur model state-space. Metode ini cukup banyak digunakan pada pemodelan pesawat udara tanpa awak, terutama yang berukuran mini dan mikro. Pada software Matlab yang digunakan, sudah tersedia tools untuk identifikasi sistem yang dinamakan SITB (system identification toolbox).

Sebelum identifikasi sistem, dilakukan pemodelan terhadap pesawat udara tanpa awak sayap tetap. Model yang dihasilkan merupakan persamaan umum dari pesawat udara tanpa awak sayap tetap. Pemodelan dan Identifikasi sistem yang dilakukan pada penelitian ini dapat dibagi menjadi 2 yaitu mode longitudinal dan mode lateral. Data terbang yang diperoleh dari pengambilan data terbang, akan diolah terlebih dahulu, yaitu dilakukan filtering dan penyesuaian parameter yang digunakan. Kemudian data terbang yang telah diolah, ditentukan data yang akan dipakai untuk identifikasi. Untuk identifikasi dibutuhkan input, output, dan sampling rate instrumentasi yang digunakan. Input untuk identifikasi sistem penelitian ini adalah defleksi elevator $\left(\delta_{\varepsilon}\right)$ dan defleksi throttle $\left(\delta_{T}\right)$, sedangkan output berupa $\Delta u, \Delta \alpha, \Delta q$, dan $\Delta \theta$. Untuk model mode lateral, input berupa defleksi aileron $\left(\delta_{a}\right)$ dan output dari sistem adalah $\Delta \beta, \Delta p, \Delta r$, dan $\Delta \phi$. Sedangkan sampling rate yang digunakan sama untuk keduan mode, yaitu $10 \mathrm{~Hz}$.

Setelah model dihasilkan, dilakukan validasi dengan mensimulasikan antara model dengan data terbang asli. Input model adalah input yang sama dengan data terbang asli. Validasi ini akan menghasilkan tingkat kecocokan grafik yang dihasilkan model dengan data terbang asli. Metode yang digunakan untuk menghitung kecocokan ini adalah menggunakan metode best fit, sesuai dengan persamaan (3).

$$
\text { Best Fit }=\left(1-\frac{|y-\hat{y}|}{|y-\bar{y}|}\right) \times 100 \%
$$

Nilai $y$ adalah nilai output data terbang, nilai $\hat{y}$ adalah nilai output yang dihasilkan model sistem yang diperoleh, sedangkan nilai $\bar{y}$ adalah nilai rata-rata dari $y$. (Mathwork, 2012). Selain simulasi output model dengan data terbang asli, akan dilakukan pula prediksi model dengan prediction tools yang ada di Matlab, tujuannya adalah mencoba menganalisa apakah model yang dihasilkan apakah kedepannya masih dapat dikembangkan lagi atau tidak. Metoe prediksi yang digunakan adalah metode prediksi 1 langkah, yaitu sistem akan melihat rekaman 1 data (history) sebelumnya. Hasil validasi akan menghasilkan apakah sebuah model layak digunakan atau tidak. Model masih dapat digunakan meskipun pada simulasi menghasilkan nilai kurang baik, selama pada prediksi menghasilkan tingkat keakuratan yang cukup baik [9].

IJEIS Vol. 5, No. 1, April 2015 : $43-54$ 


\section{HASIL DAN PEMBAHASAN}

Bagian ini akan menerangkan hasil dan pembahasan dari identifikasi sistem yang telah dilakukan pada penelitian ini.

\subsection{Hasil Pengambilan Data Terbang}

Dari pengambilan data terbang sebanyak 2 sortie, didapat data sebesar $761 \mathrm{~Kb}$ yang berisi 11.607 data. Gambar $12 \mathrm{a}, \mathrm{b}$, dan c berikut adalah data-data yang dihasilkan pada saat pengambilan data terbang.
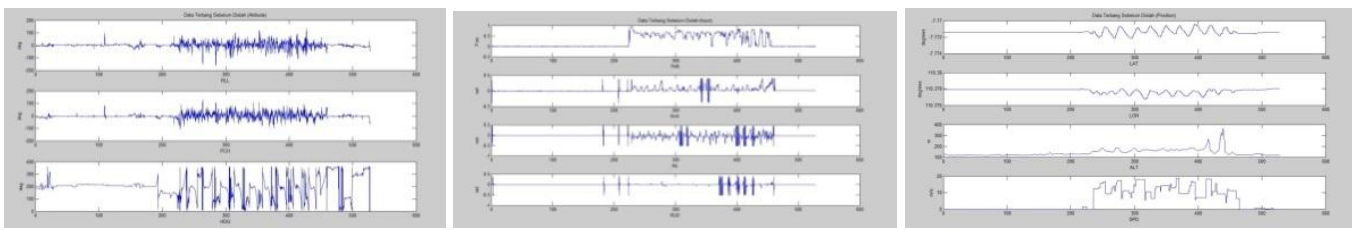

Gambar 12 Hasil pengambilan data terbang. (a) Grafik data sikap pesawat. (b) Grafik data input pesawat. (c) Grafik data posisi pesawat.

\subsection{Hasil identifikasi Sistem}

Pada proses identifikasi sistem, setelah data diolah dan disesuaikan dengan parameterparameter yang digunakan, dilakukan penentuan kondisi trim pesawat. Kondisi trim pesawat adalah saat $u \neq 0, w=0, q=0$, dan $\theta \neq 0$. Penentuan ini dilakukan secara manual. Didapatkan kondisi trim pesawat yang digunakan, yaitu pesawat RC Bixler sesuai Tabel 2.

Tabel 2 Kondisi trim pesawat.

\begin{tabular}{|cc|}
\hline Parameter & Nilai \\
\hline Sudut pitch $(\theta)$ & 0.25 \\
\hline Sudut roll $(\phi)$ & -0.28 \\
\hline Sudut defleksi elevator & 0.002 \\
\hline Sudut defleksi aileron & -0.03 \\
\hline
\end{tabular}

\subsubsection{Model terbang mode longitudinal}

Model terbang yang dihasilkan pada mode longitudinal dengan struktur state-space sesuai dengan persamaan (4).

$$
\left[\begin{array}{c}
\Delta \dot{u} \\
\Delta \dot{\alpha} \\
\Delta \dot{q} \\
\Delta \dot{\theta}
\end{array}\right]=\left[\begin{array}{cccc}
-167.9 & 80.4 & 0 & -9.505 \\
-2.029 & 0.4968 & 1 & -0.1637 \\
-0.03736 & 0.1016 & -0.6851 & 0 \\
0 & 0 & -7.734 & 0
\end{array}\right]\left[\begin{array}{l}
\Delta u \\
\Delta \alpha \\
\Delta q \\
\Delta \theta
\end{array}\right]+
$$

Model terbang ini kemudian divalidasi dan dihasilkan tingkat keakuratan model sesuai Tabel 3 berikut. 
Tabel 3 Hasil validasi mode longitudinal.

\begin{tabular}{|c|c|c|c|c|}
\hline & $\Delta u$ & $\Delta \alpha$ & $\Delta q$ & $\Delta \theta$ \\
\hline Simulasi & $-16.26 \%$ & $30.62 \%$ & $-62.55 \%$ & $2.797 \%$ \\
\hline Prediksi 1 langkah & $31.4 \%$ & $75.72 \%$ & $58.24 \%$ & $17.68 \%$ \\
\hline
\end{tabular}

Dapat dilihat hasil dari tingkat keakuratan yang dihasilkan. Metode yang digunakan untuk menilai keakuratan ini adalah metode bestfit. Metode bestfit menggunakan persamaan 3 untuk menghitung tingkat keakuratan. Karena menggunakan metode bestfit, maka memungkinkan terjadinya nilai persentase negatif. Hal ini dapat dilihat pada nilai simulasi, dimana terdapat nilai persentase yang negatif. Nilai persentase negatif memiliki kecenderungan amplitudo dari nilai simulasi yang lebih rendah dari output data terbang sebenarnya. Selain itu, dapat pula disebabkan kondisi awal (initial condition) dari simulasi berbeda jauh dengan output data terbang sebenarnya. Dengan prediksi 1 langkah, kondisi awal dari metode prediksi sama dengan output data terbang. Hasilnya dapat dilihat pada Tabel 3 dimana $\Delta u$ pada simulasi tingkat keakuratannya sebesar $-16.2 \%$ naik $47.66 \%$ hingga tingkat keakuratan model menjadi $31.4 \%$ pada prediksi 1 langkah. Kemudian pada validasi $\Delta \alpha$, pada simulasi memiliki tingkat keakuratan sebesar $30.62 \%$ naik $45.1 \%$ pada prediksi 1 langkah menjadi $75.72 \%$. Pada validasi $\Delta q$, simulasi memiliki tingkat keakuratan sebesar $-62.55 \%$ naik $120.79 \%$ menjadi $58.24 \%$ pada prediksi 1 langkah. Tingkat keakuratan naik secara drastis, karena pada simulasi $\Delta q$, kondisi awal (initial condition) berbeda jauh dengan output data terbang sesungguhnya, dengan prediksi 1 langkah, maka kondisi awal ini dapat disamakan, sehingga persentase tingkat keakuratan $\Delta q$ dapat meningkat jauh. Sedangkan yang tereakhir paada validasi $\Delta \theta$, pada simulasi tingkat keakuratan sebesar $2.797 \%$ naik 14,883\% menjadi 17,78\% pada prediksi 1 langkah.

Dengan hasil validasi tersebut, terdapat nilai keakuratan model yang rendah pada $\Delta \theta$. Hal ini dapat dikarenakan beberapa hal. Salah satunya adalah instrumentasi yang digunakan. Pitch pesawat $(\theta)$ didapat dari sensor IMU (inertial measurement unit) ADAHRS, ADAHRS yang digunakan memiliki sampling rate sebesar $10 \mathrm{~Hz}$. Sampling rate sebenarnya terlalu rendah untuk digunakan untuk identifikasi pesawat. Gerakan maksimal sebuah pesawat memiliki frekuensi sebesar $2 \mathrm{~Hz}$ [10]. Namun pada kenyataannya, untuk identifikasi sebuah pesawat, dibutuhkan instrumentasi yang memiliki kecepatan jauh diatas dari frekuensi gerakan pesawat. Untuk identifikasi gerak terbang pesawat tingkat industri, dibutuhkan instrumentasi dengan frekuensi 75-200 Hz. Selain faktor instumentasi, faktor alam yaitu angin menjadi dominan, dimana saat kita telah memberikan input terhadap pesawat, namun output yang didapat tidak sesuai. Dengan ukuran pesawat yang digunakan untuk identifikasi, yaitu pesawat RC Bixler yang cukup kecil, sehingga mudah sekali terpengaruh oleh angin.

\subsubsection{Model terbang mode lateral}

Model terbang yang dihasilkan pada mode lateral dengan struktur state-space sesuai dengan persamaan (5).

$$
\left[\begin{array}{l}
\Delta \dot{\beta} \\
\Delta \dot{p} \\
\Delta \dot{r} \\
\Delta \dot{\phi}
\end{array}\right]=\left[\begin{array}{cccc}
-0.5801 & 2.989 & -15.15 & 0.5328 \\
-0.4487 & -3.599 & -2.653 & 0 \\
0.4552 & -0.1398 & -1.278 & 0 \\
0 & 1 & 0.25 & -0.4392
\end{array}\right]\left[\begin{array}{l}
\Delta \beta \\
\Delta p \\
\Delta r \\
\Delta \phi
\end{array}\right]+
$$

IJEIS Vol. 5, No. 1, April 2015 : $43-54$ 


$$
\left[\begin{array}{c}
0 \\
-0.1831 \\
0.135 \\
0
\end{array}\right]\left[\Delta \delta_{\alpha}\right]
$$

Model terbang ini kemudian divalidasi dan dihasilkan tingkat keakuratan model sesuai Tabel 4 berikut.

Tabel 4 Hasil validasi mode lateral.

\begin{tabular}{|c|c|c|c|c|}
\hline & $\Delta \beta$ & $\Delta p$ & $\Delta r$ & $\Delta \phi$ \\
\hline Simulasi & $-6.803 \%$ & $-9.45 \%$ & $17.1 \%$ & $-7.243 \%$ \\
\hline Prediksi 1 langkah & $11.96 \%$ & $63.18 \%$ & $47.42 \%$ & $45.28 \%$ \\
\hline
\end{tabular}

Pada validasi model terbang mode lateral, didapatkan beberapa nilai simulasi yang negatif. Kasus ini mirip dengan validasi model terbang mode longitudinal. Hal ini dipengaruhi oleh kondisi awal (initial condition) dari simulasi yang dihasilkan memiliki perbedaan dengan output data terbang sesungguhnya. Selain itu nilai negatif ini juga dipengaruhi perbedaan amplitudo antara simulasi dengan output data terbang sesungguhnya. Nilai keakuratan model dapat diperbaiki dengan validasi dengan metode prediksi 1 langkah. Dengan prediksi 1 langkah, tidak ada lagi nilai keakuratan dibawah nol (minus). Terjadi peningkatan nilai keakuratan dari $6.803 \%$ menjadi $11.96 \%$ untuk $\Delta \beta$. Kemudian $\Delta p$ terjadi peningkatan nilai keakuratan yang cukup signifikan dari $-9.45 \%$ menjadi 63.18. Untuk $\Delta r$ mengalami peningkatan keakuratan sebesar $30.32 \%$, dari $17.1 \%$ naik menjadi $47.42 \%$. Kemudian yang terakhir $\Delta \phi$ meningkat keakuratannya sebesar $52.523 \%$. Terdepat nilai keakuratan yang rendah yaitu $\Delta \beta$. $\beta$ adalah sideslip yaitu kondisi dimana ketika pesawat terbang lurus ke depan tetapi kenyataannya pesawat terbang tidak lurus (menyamping). Hal ini adalah kondisi yang wajar pada setiap pesawat, karena dengan adanya vertical stabilizer dipesawat, pada saat-saaat tertentu dimana angin cukup kuat, maka aka nada gejala sideslip. Sehingga nilai keakuratan $\Delta \beta$ pada penelitian ini dapat dimaklumi, karena disaat pengambilan data terbang, beberapa kali pesawat sempat terbawa angin, sehingga terbang tidak sesuai input kontrol yang diberikan.

\section{KESIMPULAN}

1. Telah dihasilkan model matematika yang dapat merepresentasikan gerak terbang pesawat udara tanpa awak sayap tetap jenis Bixler.

2. Persamaan model terbang yang dihasilkan:

- Model terbang pada mode longitudinal dengan struktur state-space sesuai dengan persamaan (4)

- Model terbang pada mode lateral dengan struktur state-space sesuai dengan persamaan (5).

3. Nilai keakuratan yang diperoleh dari masing-masing model:

- Model terbang mode longitudinal memiliki keakuratan sebagai berikut:

o $\Delta u$ memiliki nilai keakuratan sebesar $31.4 \%$.

o $\Delta \alpha$ memiliki nilai keakuratan sebesar $75.72 \%$.

o $\Delta q$ memiliki nilai keakuratan sebesar $58.24 \%$.

o $\Delta \theta$ memiliki nilai keakuratan sebesar $17.68 \%$.

- Model terbang mode lateral memiliki keakuratan sebagai berikut:

- $\Delta \beta$ memiliki nilai keakuratan sebesar $11.96 \%$. 
- $\Delta p$ memiliki nilai keakuratan sebesar $63.18 \%$.

- $\Delta r$ memiliki nilai keakuratan sebesar $47.42 \%$.

- $\Delta \phi$ memiliki nilai keakuratan sebesar $45.28 \%$.

4. Penentuan kondisi trim pesawat menjadi bagian penting dalam pemodelan gerak terbang pesawat udara.

\section{SARAN}

Untuk penelitian selanjutnya, diperlukan instrumentasi yang memiliki sampling rate yang cepat dan akurasi yang tinggi untuk identifikasi sistem. Selain itu diperlukan penelitian pada bentuk stuktur model yang lain agar dapat dibandingkan dengan penelitian ini.

\section{DAFTAR PUSTAKA}

[1] Ljung L., 2011, System Identification Toolbox ${ }^{\mathrm{TM}}$ User's Guide, The MathWorks, Inc., Natick.

[2] Söderström T. dan Stoica P. , 2001, System Identification, 2, Prentince Hall International, London.

[3] Masiero C., 2012, Matlab System Identification Toolbox Quickstart, http://automatica.dei.unipd.it/tl_files/utenti2/masieroChiara/Miscellanea/Matlab_SysId_Tut orial.pdf, diakses tanggal 23 November 2013.

[4] McLean, D., 1990, Automatic Flight Control System, Prentice Hall Inc.

[5] Hobbyking, 2011, Bixler v1.1 EPO 1400mm, http://hobbyking.com/hobbyking/store/_16543_Bixler_v1_1_EPO_1400mm_RTF_Mode_ 1_Throttle_Right_Radio_html, diakses pada 20 November 2013..

[6] Pratama F., 2013, Sistem Referensi Air Data, Attitude, And Heading Reference System Pada Pesawat Terbang Tanpa Awak, Skripsi, Fakultas Matematika dan Ilmu Pengetahuan Alam, Universitas Gadjah Mada, Yogyakarta.

[7] Sparkfun, 2013, Micro SD Shield, https://www.sparkfun.com/products/9899, diakses tanggal 1 November 2013.

[8] Smith, M. S. dan Moes, T. R., 2003, Real-time Stability and Control Derivative Extraction from F15 Flight Data. AIAA Atmospheric Flight Mechanics Conference, AIAA-20035701.

[9] Oksa, M., 2012. Identifikasi Sistem Pada Perilaku Pesawat Terbang Tanpa Awak, Skripsi, Fakultas Matematika dan Ilmu Pengetahuan Alam, Universitas Gadjah Mada.

[10] Tischler, M. B., 2006, Aircraft and Rotorcraft System Identification, Engineering Methods with Flight Test Examples, American Institute of Aeronautics and Astronautics. 